УДК 373.2:37.09(435.9)

DOI: $10.18384 / 2310-7235-2019-2-106-125$

\title{
PROFESSIONALIZATION OF GERMANY'S DAY CARE SYSTEM FOR YOUNG CHILDREN - ON THE RELATIONSHIP BETWEEN PRACTITIONERS, STRUCTURES AND CONTEXTS
}

\author{
T. Friederich, G. Schoyerer \\ Katholische Stiftungsfachhochschule München
}

Preysingstraße 83, 81667 Munich, Germany

Abstract. The present article examines the conditions for professional pedagogical practice, starting with the question of what professionalization in children's day care means and how the term is discussed, especially in Germany. This enquiry into professionalization focuses on how it can improve pedagogical quality, and what factors this can be attributed to. The analysis begins with selected perspectives from the discourse on professionalization in early education research.

Keywords: early education, children's day care means, selected perspectives, professionalization.

\section{ПРОФЕССИОНАЛИЗАЦИЯ НЕМЕЦКОЙ СИСТЕМЫ ДНЕВНОГО УХОДА ЗА МАЛЕНЬКИМИ ДЕТЬМИ - О ВЗАИМООТНОШЕНИЯХ МЕЖДУ ПРАКТИКАМИ, СТРУКТУРАМИ И КОНТЕКСТАМИ}

\section{Т. Фридрих, Г. Шойерер}

Католический университет прикладных наук г. Мюнхена

Preysingstraße 83, 81667 Munich, Germany

Аннотация. В данной статье исследуются условия профессиональной педагогической деятельности, начиная с вопросов о том, что понимается под профессионализацией в дошкольной организации и как этот термин воспринимается в Германии. Использование термина обусловлено стремлением выявить прежде всего то, как это может улучшить качество преподавания и каким факторам это может быть приписано. Анализ начинается с обзора выбранных перспектив как результатов дискуссий в исследовании профессионализации в раннем образовании.

Ключевые слова: раннее образование, дошкольные организации, профессионализация, качество образования

\section{Professionalization of the workforce in early childhood education settings \\ Early childhood education and care has grown in importance during the past three decades. This has led to profound}

changes in the early childhood education systems in different European countries, as shown in documents of UNESCO and the European Union $[81 ; 82 ; 83 ; 31]$. The idea behind early childhood educa-

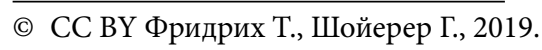


tion is to stimulate children's learning as early as possible in order to create better chances for education, job opportunities and life satisfaction. Research has shown that early childhood education can improve children's life chances in important ways [38]. Particularly high quality day care settings contribute towards positive child outcomes. Thus the question of how to improve the quality of early childhood settings is a central issue, both in Europe and internationally.

Across countries, there is consensus that quality is a multidimensional concept and that attempts to improve quality need to address different levels. This understanding forms the basis of the Early Childhood Environment Rating Scale (ECERS), an instrument which measures various items of centre-based quality. This approach, however, remains limited to the internal space of the day-care setting, and may exclude relevant areas that lie outside the facility but nevertheless have a significant impact with regard to aspects of quality. Besides assessing criteria relating to orientation quality (pedagogical approach and core principles and values of the early years practitioner) and to process quality (pedagogical processes and dynamics such as providing stimuli and interactions tailored to children's needs), these studies also point to the importance of structural quality relating to working conditions, such as the staff-to-child ratio $[80 ; 59]$. However, structural quality has no direct effect on the overall quality, rather it moderates process quality [59]. In fact, empirical studies show that almost half the differences in process quality can be attributed to "differences in the basic conditions of structural and orientation quality" [79; 77]. International studies using comparable assessment instruments have come to similar conclusions $[37 ; 23]$. This suggests that on the one hand the workforce plays an important role in process quality, but on the other hand structural quality can make a difference.

In other countries, there are similar questions and concerns about the qualification of the workforce in day care centres. Oberhuemer and Schreyer [55] point out that there is no common approach towards early childhood qualification requirements in Europe. A number of research studies have shown that an academic qualification does not necessarily lead to improved child outcomes $[29 ; 4]$. Continuing professional development is a promising approach towards improving the quality of the workforce $[59 ; 60]$, but it does not answer the question about the best preparation for the work.

These questions are frequently discussed under the term "professionalization". However, the term is often used to refer solely to improvements in the individual practices of early years practitioners, with the aim of enhancing quality [20]. It has often been pointed out, however, that the individual level of pedagogical practice is not enough, on its own, to raise the quality of children's day care experiences [84; 79].

The present article examines the conditions for professional pedagogical practice, starting with the question of what professionalization in children's day care means and how the term is discussed, especially in Germany. This enquiry into professionalization focuses on how it can improve pedagogical quality, and what factors this can be attributed to. The analysis begins with selected perspectives from the discourse on professionalization in early education research. A further step will be to present the CoRe study [85], which of- 
fers important information for reflections on the children's day-care system. The third section, taking the CoRe study as its starting point, develops multidimensional perspectives on professionalization in the day-care system, and presents the current status quo in Germany. The comprehensive approach taken means that it is not possible to discuss all the relevant aspects in depth. The authors have therefore chosen an overview-type presentation giving an idea of the "big picture". The article ends with a summary, and a preview of possible future developments.

\section{Conceptual and empirical perspectives on professionalization}

The debate about professionalization in early education research essentially revolves around the issue of improving the quality of children's day care. As in many other countries, there are different forms of day care for young children. In Germany, children's day care encompasses both day-care centres and childminding services ${ }^{1}$. The debate about professionalization, however, relates almost solely to the qualifications and competencies of the practitioners in day-care centres [85]. In childminding, on the other hand, the predominant discourse relates to child and youth welfare, and includes discussion about the professionalization of sociopedagogical areas of work, such as professional advisory and support services [64]. Moreover, the concept of professionalization seems inappropriate for childminders, since the majority of active childminders (around 70\% [70]) have had no pedagogical training, which is seen as the prerequisite for professionalization [75].

There are different perspectives on professionalism in children's day care. Internationally, professionalism "is com- monly understood as an apolitical construct broadly defined by the acquisition of specialist knowledge/qualifications, the ability to meet high standards, to self-regulate and to exercise high levels of autonomy" [57]. And even if these requirements do not reflect the reality of the workforce in early childhood education, there is a demand for professional day care and for staff who can provide high quality education and care ${ }^{1 \mathrm{a}}$.

With regard to the professionalization of early years practitioners in Germany, a number of additional issues can also be identified. While for many years having the "right" qualification was virtually the only concern, in recent years a new view has become dominant: what matters is not so much the practitioners' qualifications, as their pedagogical practice $[8 ; 21 ; 74$; 20]. The aim of professionalization is to improve practitioners' practices in terms of quality and, ultimately, the resulting effects on children and families $[74 ; 2]$. There are, however, differences of opinion about how this professional practice is to be achieved.

Thole [74] identified various perspectives, which consider professionalization in the light of different key issues ${ }^{2 b}$.

The formal model stands for professionalization through academization, or formal qualification. It is expected that (university-

\footnotetext{
We use the term "childminding" to refer to home-based settings mainly for children under three years of age. In Germany $15 \%$ of early child care for under threes is provided by childminders [6].

2 Thole explains that the classic categories from the theory of the professions do not work for childhood education, since most of those employed in this field cannot be considered "professional" when measured against the indicators for professions [74]. Thole therefore concentrates on case-related and field-related concepts.
} 
level) education and training will create the prerequisites for competent practitioners, who will in turn contribute to high quality practices [76]. Empirical studies from the Anglo-American world, however, are unclear on this issue. While research findings from the English project "Effective Provision of Pre-School Education" (EPPE) report positive effects of practitioners' level of education on the quality of pedagogical processes [73], Early et al. [29] suggest that it is the relevance of the training, regardless of the level of the qualification, that leads to high process quality. There are as yet no German studies that are able to cast light on this matter, and it is not known to what extent these findings can be transferred to the German situation [2]. In the German debate, the current assumption is that collaboration between graduates from universities and vocational schools contributes to higher quality. Against this background, the Aktionsrat Bildung (Action Committee for Education') calls for the discontinuation of training in vocational schools in the medium to long term [2]. Given the shortage of staff, however, and the low number of graduates from degree courses in early childhood education, this scenario still seems to be some way off [62].

These remarks refer to the institutional side of children's day care. By way of contrast, childminders have, on average, a considerably lower level of formal qualification. However, empirical studies on pedagogical quality and child development parameters have so far shown them to be on a par with day-care centres. The NUBBEK study [77], for example, compared descriptive results from childminding services and nursery groups, taking into account criteria relating to the measurement instruments implemented, and found hardly any difference in the level of pedagogical quality. Both centre-based and home-based settings achieved medium-level scores for pedagogical quality. In seeking a possible reason for this, the authors point to a possible over-representation of "larger childminding facilities and childminding facilities with higher pedagogical qualifications" [77, p. 15]. This finding is somewhat confusing, given that the proportion of carers with pedagogical training is much higher among day-care staff than childminders.

The confusion increases if we look at the studies by Ahnert [1] and Ahnert et al. (2012). These were able to demonstrate that children cared for by a childminder showed significantly higher values for attachment quality, and, on average, higher values for cognitive development, than children in centre-based settings with fully trained educators (Erzieher/Erzieherinnen). The surprising thing here is that the good results of children cared for by childminders may have quite different causes, since the sample used by Ahnert (2010) and Ahnert et al. (2012) included various types of childminder in comparably sized samples. Thus this result cannot be ascribed solely to the degree of professionalization or qualification of the childminders studied.

These findings suggest that there is some doubt about the appropriateness of qualification as a predictor of pedagogical quality. Since the debate has now moved from qualifications to the competencies of early years practitioners and childminders, the formal model of professionalization can be regarded as outdated with regard to quality-related matters.

Another perspective on professionalization is offered by the indicator-based model of professionalization, which has its roots in the sociological theory of the 
professions. This model points to a process of professionalization extending over four phases: the activity is first defined as a distinct occupation or vocation (Verberuflichung), then as a subject or discipline (Verfachlichung), then academized and professionalized [74]. With reference to the classic theory of the professions developed by Parsons, indicators are identified which are attained in the process of professionalization and which lead to the emergence of a profession. Indicators include academic training, access barriers, agreed professional ethics, the presence of a professional organization, and a high societal status $[24 ; 22]$. A process of professionalization is considered to be complete when "people with a relevant academic qualification" [74], i.e. a degree in child pedagogy or social pedagogy, have interpretive power over children's day-care facilities as an area of work. This indicator model is now also seen as unsuitable, since it refers to the concept of a profession whose existence is a matter of fundamental doubt in modern societies [71; 40].

This model needs to be distinguished from case-related and field-related models of professionalization or pragmatic models of professionalization [76], which measure the degree of professionalism on the basis of practitioners' self-reported levels of expertise. Here the autonomy of the practitioners is emphasized, and pedagogical interactions take centre stage Examples for such approaches are the studies of Beher and Walter [12] and Cloos [21]. Mention should also be made of evidence-based or efficiency-based models of professionalization, which focus on the effectiveness of pedagogical practice or its efficiency and economic viability, in terms of cost-benefit ratios. These perspectives, however, do not advance us any further with regard to the improvement of quality, especially process quality $[74 ; 76]$.

Lastly, Thole [76] mentions models of professionalization based on competence diagnosis. In these, particular characteristics of competence are understood as elements of professionalism. Here competency profiles serve as reference points; these are developed on a theoretical basis and show, on various discipline-related levels, what skills are needed by practitioners in order to cope with the demands made of them $[32 ; 42]$. The competency profiles, however, are idealistic descriptions and lists of what are initially "rigid" competency requirements, which may or may not be relevant in the situative practice of pedagogical activity. In the end it is only in performance, i.e. in the practitioners' actions in a concrete situation, that it becomes evident to what extent these theoretically defined competencies are actually used by practitioners, and what type of competencies have what effects in the specific situation. For this, one would need to assess practitioners' competencies in specific situations, and investigate what competencies actually lead to higher quality. So far, however, there are few instruments available for early education research (cf project "Kompetenzbasierte Profungs- und Feedbackverfahren in unterschiedlichen frohpddagogischen Aus- und Weiterbildungsstrukturen" ("Competencebased testing and feedback procedures in different early childhood training and professional development structures").

Mention should also be made of evidence-based or efficiency-based models of professionalization, which focus on the effectiveness of pedagogical practice or its efficiency and economic viability, in terms of cost-benefit ratios. These perspectives, 
however, do not advance us any further with regard to the improvement of quality, especially process quality $[74 ; 75]$. The quality model devised by Tietze et al. [79; 80] is an example of an evidence-based model of professionalization, since it uses an evaluation concept to determine the quality in the day-care centres, and develops suggestions for improvement based on the result. This is then understood as a professionalization strategy.

It is striking that the majority of models of professionalization focus entirely on the practitioners as the key factor for improving quality in children's day-care centres. There are now clear indications, however, that the quality of pedagogical practice depends on a number of factors.

\section{Competent day-care systems: The CoRe study}

The CoRe project $[84 ; 85]$ engaged in a multidimensional examination of professionalism and professionalization in the field of children's day care. The central question was what a competent day-care system would have to be like in order to ensure high quality. An empirical transEuropean comparison of systems of early childhood education and care was used to identify core aspects of a competent system, aspects that may be helpful for the professionalization of the day-care system in Germany.

Four levels were identified:

- individual level

- institutional and team level

- inter-institutional level

- political level [85].

The authors point out that the individual level, i.e. the competencies of early years practitioners, has considerable importance for the quality of the system. They also stress, however, that the quality of the practitioners can only develop to its full potential in a system that is "competent" [85]. A competent system emphasizes reciprocal relationships between individuals, teams, institutions and the political level. The study therefore highlights conditions and support structures which the early years practitioners need to be able to rely on if they are to deal responsibly and competently with the needs of children and parents [84]. With this understanding of competence, they expand the prevailing individualized concept of competence to include an institutional, inter-institutional and political level. The core element of a competent system, then, is a focus on the different needs of those involved in this system (parents, society, and politics). An improvement in quality has to relate to the whole system [85].

This broader understanding is described in terms of new areas of competence, which indicate that competence goes beyond individual stores of knowledge, skills, motivations etc. The authors stress that "a key finding of CoRe is that 'competence' in the early childhood education and care context has to be understood as a characteristic of the entire early childhood system" [85]. In order to be able to describe the competence of the system, Urban et al. developed the categories of "knowledge, practices and values", which are relevant for all the levels. They explain this decision as follows: "by referring to practices instead of skills we intend to distance ourselves from a technical conceptualisation of educational work (do I do things right?) to move toward its intrinsically reflective nature (do I do the right things?). Similarly, by referring to values instead of attitudes we intend to distance ourselves from an 'individualised' conceptualisation of ECEC purposes to move toward a vision of early childhood education that under- 
pins negotiated goals and collective aspirations" [85]. One advantage of a thus-defined 'competent' system is that it allows nuanced approaches to children's day-care systems, transparent approaches that can take into account local and regional conditions and give nuanced descriptions of suitable places for children and families [84]. This expanded view of the day-care system (1) focuses attention on the connections between individual, organization and institution, and on the political dimensions that define them, and (2) points to the related needs in terms of knowledge, practice and areas of values. The CoRe study therefore emphasizes the fact that quality in early childhood education and care depends on much more than the competencies of the practitioners.

These are the central findings of the CoRe study, and the key elements of a competent system:

1. Children's day-care systems develop into competent systems when a coherent public policy is operating in the background, based on cooperation with the most important interest groups. In addition to this, it is easier for a system focused on the common good to reach a high level of professionalism [85].

2. Curricula and competency profiles help to ensure that there is discussion about the values, purpose, aims and content of education and training. National qualifications frameworks standardize training and professional development, as well as informal learning [84].

3. Precarious employment situations have a detrimental effect on individual learning and therefore on the professionalization of the field. "The quality of the workforce cannot be reduced to the sum of the individuals' competences. ... Among the more salient aspects of systemic conditions that allow for competence systems to flourish are good working conditions that reduce turnover of staff and continuous pedagogical support, aiming at documenting practice, critically reflecting upon it, and co-constructing 6 pedagogy as an alternation between theory and practice. This requires time, team collaboration and continuous pedagogical support" [85].

4. Unitary childcare systems foster coherent policies, greater professionalism, higher qualifications and higher wages. The CoRe study also shows that educational practitioners with a broad focus have a deeper understanding of the subject matter than specialist practitioners. The Danish paedagoger are cited as an example: they complete a socio-pedagogically oriented bachelor-level course and are trained to work with both children and adults, potentially ranging in age from 0 to 99 [84].

5. There is empirical evidence that investments in education and training are effective if they are followed by ongoing professional development or professional advice and support from well-trained staff [84]. "Continuous professional development, accompanied by specially qualified staff needs to take place over extended periods of time and to be focused on transforming collective and individual practices" [84].

6. The majority of early childhood practitioners are still female, suggesting that there is a widespread belief that care work is women's work. The long-term goal should be to raise the proportion of men in childcare systems to $10 \%$ [85].

The following section examines the various levels of a competent system, and looks at empirical studies to find evidence of competence in the German day-care system. 


\section{Professionalization in the context of a multidimensional system}

It has become clear by now that professionalization, in the area of children's day care, goes far beyond the level of qualifications, and that different dimensions of the system need to be taken into account. This section deals in turn with each of the levels that have been found to be important, and discusses - with reference to empirical studies - selected issues related to the situation of children's day care in Germany, issues that the authors see as influencing the pedagogical actions of practitioners.

\section{- Individual level: pedagogical practice, biography and competence}

In recent years many efforts have been made in Germany to improve or extend the qualifications and competencies of early years practitioners. ${ }^{3}$ In 2004, bachelor's degrees in early childhood education were introduced because of different reasons. One of them was to raise the formal level of qualification of employees in day-care centres in Germany, because it was lower than that in most other European countries [56]. What the OECD study did not take into account was the fact that, in most other European countries, day-care centres employ not just practitioners with bachelor-level training, but also assistants with a much lower level of training or none at all $[33 ; 85]$. In Germany, as already suggested above, the discussion here refers to individuals with specialist pedagogical training.

7 care facilities employ Erzieher and Erzieherinnen with three-year training ${ }^{\text {lc }}$.

1 The actual training lasts three years in most cases, based on a two-year preliminary qualification. It's a post-secondary qualification, beginning at minimum age 18 , whereas the upper secondary models begin at an earlier age.
Just under $70 \%$ of those employed in children's day-care centres have completed this training [6]. Furthermore, this is a broad-spectrum training programme, which, according to Urban et al. [84], might help to achieve a higher pedagogical quality than practitioners who have specialized in early childhood education.

The individual level is also important in political terms, as shown by the efforts to expand the current qualifications landscape: the framework curricula for Erzieher/innen have been revised and translated into a competence-oriented format $[7 ; 44]$. Along with this, part-time programmes of study have been established to give trained Erzieher/innen the opportunity to gain further qualifications while they work. There have also been calls to abolish courses for Kinderpfleger/innen (childcare workers) or Sozialassistent/innen ('social assistants'), the second-largest group of employees in this field at nearly $14 \%[6 ; 2]$. In addition to this, there are numerous professional development initiatives and projects, designed to extend and improve the competencies of the practitioners employed in day care. There is, however, no coherent system of training and professional development for the practitioners in day-care centres; no system in which the qualification profiles earned are integrated and build on each other. There have also been major changes in the childminding sector in recent years, thanks to the Aktionsprogramm Kindertagespflege (Action Programme for Childminding), funded by the Federal Ministry of Family Affairs, Senior Citizens, Women and Youth - even if there are as yet few binding guidelines for qualifications in the individual federal states [58].

These activities show that a great deal of attention is being paid to early years practitioners and their training. On the 
basis of the current state of research, the extent to which pathways of mainly academic training and professional development are able to increase the quality of pedagogical practice remains largely unknown. As shown above, the level of formal qualification alone is no guarantee. Several studies refer to the positive self-assessment of Erzieher/innen with regard to the professional responsibilities facing them $[39 ; 3 ; 21]$. However, they feel increasingly unprepared when they have to cope with tasks outside everyday work issues [26; 74]. The explanation offered for this discrepancy is insufficient reflexive analysis of the connections between biographically shaped areas of knowledge and ability, and the academic forms of knowledge of early years practitioners [48; $21 ; 74]$. These need to be initiated within the framework of (university-level) education and training, and supported within the framework of processes leading into and accompanying practice - as a kind of occupational or professional socialization. We should also bear in mind that with only an estimated 1000 universityeducated (BA) graduates per year, as opposed to roughly 19,000 graduates from vocational schools, those with university degrees make up only a small proportion of the total of 310,000 Erzieher/innen working in children's day care [61]; it can therefore be assumed "that the volume of academically trained practitioners in evidence so far will not, in the foreseeable future, change the field in qualitative terms, let alone in quantitative terms" [61, p. 26].

Furthermore, there are other factors that influence the degree to which early years practitioners are actually able to develop competencies and show their effects. After all, practitioners are individuals who are not only socialized through their train- ing and professional practice, but whose practice is also shaped by personal beliefs and biographical experiences. These can sometimes override the professional socialization related to their qualifications and their work. Thus there are several indications that practitioners' pedagogical orientations and attitudes are, on the one hand, embedded in underlying personality dispositions. Due to their biographical character, these are relatively stable [26; $21 ; 74]$. On the other hand, it has become clear that this connection may be more dynamic than previously supposed, and that certain "background variables" (such as value judgements) can have an impact on pedagogical orientations [53]. Studies on teachers' processes of assessment and selection suggest that attempts are made to compensate for a lack of institutional and professional framing with individual moral judgements - particularly in challenging situations and dilemmas $[51 ; 5]$. These findings indicate that, as well as the practitioners themselves, the underlying conditions can play an important part in professionalization, even in children's day care.

A further difficulty when considering competencies with a view to increasing the professionalism of practitioners is the question of where - along what lines - professionalism can manifest itself, between intuitive and intentional pedagogical practice. This question still seems largely unresolved, even if certain forms of knowledge are widely regarded as necessary [48]. Fundamental connections have already been pointed out several times [54]. Of particular interest in this context are the insights from biographical research on the connection between biographical processes and processes of system regulation in the welfare state. For 
example, Mayer and Mbller [52], starting from Kohli's concept of the "institutionalized life course" [46; 47], argue that the life course is structured to a considerable extent by the services offered by the welfare state, which sets up institutionalized programmes of education and stateaccredited training courses, shapes careers through wage-setting mechanisms, or establishes social security systems.

This not only sheds light on the individual level of professionalization and its relationship to biographical and personal dimensions of the practitioner, but also encourages us to look at different levels of the system, within which practitioners can operate and, in various ways, develop and use their competencies [26].

\section{- Institutional and team level: work structures and operating conditions}

It is now considered beyond dispute that professional pedagogical practice is dependent on a structural or institutional framework [84]. Thus it has been shown a number of times that favourable structural dimensions, such as small groups or a low number of children per care practitioner, have a positive effect on the quality of pedagogical processes [30; 49; 59]. It has also been pointed out, however, that structures only have effects on pedagogical processes through the intermediary 9 of the practitioners; they therefore cannot explain more than half of the variance in pedagogical quality [77]. Wertfein et al. [88] were able to show these mediating effects of the team in a recent study; they point out that closely coordinated and collaborative working methods in the team have positive effects on the interactive behaviour of practitioners towards children, but that no independent influence of underlying structures on the quality of inter- action could be observed. With regard to work methods in teams, we should also bear in mind the insight from Cloos [21] on dynamics and practices of differentiation within teams; it can be assumed that these will also have an impact on the solidarity and the atmosphere among staff.

Another factor seen as having a significant impact on quality is the management of children's day-care centres [2;87]. Although there have as yet been few empirical studies on this issue, and although there are a wide range of opinions on the prerequisites for taking on a managing role in day-care centres $[72 ; 15 ; 11]$, it can be assumed that management plays a major role in determining the practice and culture in the centres. Moreover, the Aktionsrat Bildung observes, referring to the EPPE study, that "the higher the qualification ..., especially of those managing the centres, the higher the observed quality of support in the centres, and the greater the developmental progress made by the children" [2]. For the German situation, there are as yet no studies on the influence of management on pedagogical quality and teamwork.

A good team atmosphere, as shown by Viernickel \& Voss [86] in the Stege study, is a significant protective factor against health problems in day-care centres, to which early years practitioners are considerably more vulnerable, on average, than women of the same age with the same education in the German population as a whole. The increase in physical and mental stress, and the risk of a reduction in work capacity are, according to the authors, clearly correlated (factor 2-2.5) with unfavourable structural conditions such as poor financial and spatial resources, poor ergonomic working conditions, chronic time pressure, constantly increas- 
ing work requirements, or exposure to excessive noise. Barthel et al. [9] also refer to increased health and stress issues, taking into account the different priorities in day nurseries and kindergartens.

It therefore seems natural to assume that persistently unfavourable work conditions and structural conditions have a particularly negative impact on team structures and pedagogical processes. Urban et al. [85] also emphasize the importance of "good working conditions", pointing to the importance of stable, longestablished teams, and a low level of staff turnover. In a recent study, Viernickel et al. [87] also allude to the relative dissatisfaction of early years practitioners with regard to the number of children per group and the staff-child ratios in the centres (earlier mention of this in Kahle 1999 [41]). In the Aqua study, Schreyer et al. [68] similarly point to a link between growing dissatisfaction with work and poor working and / or employment conditions. They also show that good working conditions can have a positive effect on job satisfaction and reduce perceptions of stress. A further factor contributing towards stressful working conditions lies in the time constraints facing practitioners. Practitioners surveyed in the Stege study felt that the formally allocated time for indirect pedagogical tasks such as parent conferences or documentation was too short [86]. This is not surprising considering the staffing ratios in day-care centres, which in some cases are far above the recommended level [13].

\section{- Inter-institutional level:}

funding bodies, collaboration and professional support

Tietze \& Lee [78], in their expanded quality model, have already pointed out factors relevant for quality which lie outside the internal space of the day-care centres. They assume that certain broader contexts serve as mediating variables between structural, orientation and process quality. This may be understood to include, for example, the way funding bodies, collaborative and network relationships, and external advice and support influence the pedagogical practice of the practitioners.

The service providers (Trdger) and funding bodies which operate day-care centres play an important role at the inter-institutional level. The funding bodies shape the structural conditions and the pedagogical programme of the day-care centres, and select the staff. So it is these bodies that determine the composition of the staff and the occupational groups represented, thus influencing the development of the field [43]. In Germany, there is a very heterogeneous mix of public (34\%) and independent youth welfare funding bodies $(66 \%)$, each of which has a different "degree of professionalization" (cf. [6]). It can be assumed that the quality of the practitioners' practices is also influenced by the ideological and normative priorities of the funding body. At the same time, practitioners bring their personal beliefs into the facility, and may espouse different values to the funding body. This can, as shown in a study in Protestant daycare centres, have a negative impact on their self-understanding, their work motivation, and their support for religious education and care $[27 ; 28]$.

With regard to collaboration, Section 22a of the German Social Code VIII (SGB VIII) stipulates that public funding bodies are obliged to ensure collaboration between practitioners in day-care centres and various social and public institutions, 
as well as the local community, in order to be able to provide services that meet the needs of children and families. Van Santen [63] shows, however, that more than a third of facilities (37\%) do not offer any services targeting families or the local community, beyond the education and care of children. This can be seen as an area in need of improvement, especially as - given the heightened expectations of children's day care and the changes in society - inclusive and collaborative concepts are currently regarded as the best way forward (Schoyerer/van Santen under review). These include expanding the functions of day-care centres, in response to the needs of the local community ("family centres"), or centralizing the management of day-care services within a locality or region. Beher and Walter [12], however, have pointed out that early years practitioners see themselves as lacking competence in creating and maintaining collaborative relationships with other facilities and actors in the local community. This is alarming, especially since the need to create an inclusive education system will place ever greater demands on collaborative relationships in the future [45].

External professional advice and support for children's day-care services can be seen as another facet of context quality. This is aimed at initiating, sustaining and developing quality, and is focused not just on giving individual advice to practitioners, but also on organizational issues, i.e. the system of funding bodies and the structural conditions associated with it $[25 ; 67 ; 17]$. Professional advisory services are provided by public or independent funding agencies with the aim of supporting the management of day-care centres, practitioners and educators, helping them to create services that are suitable for children and parents from a qualitative and organizational point of view, and to align these services with their statutory mandate. While an entitlement to professional support for the area of children's day-care centres can only be deduced indirectly from Section 22a of the German Social Code VIII (SGB VIII), professional advice and support for both childminders and parents or carers whose children are cared for by childminders is explicitly set out and regulated as a statutory obligation in Section 23 of the German Social Code VIII (SGB VIII).

However, the field of professional mentoring and support for children's day care is, in practice, very heterogeneous. A key feature is that these support services have to perform a large number of tasks with different priorities. The areas of work include day-care-related tasks in a narrower sense, such as giving advice and support on the management, or the conceptual and organizational development of day-care centres; coordinating, networking and improving the qualifications of practitioners; and quality assurance and quality management, as well as administration and monitoring $[16 ; 50 ; 12]$. Professional advice and support in the childminding sector has a similarly wide range of responsibilities [58], though it can be assumed that professional support for childminders has to provide additional services, in order to (1) give adequate information and advice to the mainly self-employed childminders, and (2) appropriately fulfil its official responsibility in connection with aptitude testing and the issuing of childminding licences $[65 ; 19]$.

Professional advice and support can also refer to on-the-job support (Praxisbegleitung), but this is usually understood as an internal, collegial or super- 
visory service offered by day-care centres. So far there has been virtually no research in the German-speaking countries on the subject of professional support and its effects in the field of children's day care. A European meta-analysis has shown that training can improve the competency of the workforce [36]. American studies, however, suggest that coaching-style support for practitioners is the most effective form of continuous professional development, and brings about a lasting change in their practices. On-thejob professional support, however, is the most expensive, time-consuming, and resource-intensive form of professional development.

\section{- Political level: workplace, status and occupation}

On the one hand, the underlying conditions for children's day care on an individual, institutional and inter-institutional level influence dimensions of pedagogical quality. On the other hand, these areas are for their part dependent on structures. This broader context includes, in particular, the level of agenda setting in sectoral policymaking, such as legal requirements on federal and state level, implementing regulations and bylaws, and financial and administrative guidelines. However, it is not possible within the framework of this article to refer to these aspects in any detail. The following section identifies aspects relating to the workplace, status and vocation of educators, aspects that underlie the structures of children's day care.

In general, a vocation is understood as a set of activities that

1. requires specific knowledge and skills (usually acquired through training),

2 . serves to secure and maintain one's livelihood ("ensuring survival"), and
3. is intended to be a long-term occupation.

If we consider the current occupational situation of educators in children's day care in the light of these requirements, we find points of divergence, some of them substantial. This particularly applies to the area of childminding. Here, for example, discrepancies are visible in relation to the demand for specialized knowledge and skills. In $2013,32 \%$ of the active childminders in the public childminding system had had some form of pedagogical training, with $14 \%$ of these having trained as Erzieher / innen [70]. Another disparity appears when it comes to the question of earning a living. Taking into account considerable variation in the remuneration of childminders, on the level of the youth welfare office [69], childminding cannot necessarily secure one's livelihood, even if the childminder takes in the maximum number of five children [67]. Lastly, the requirement that a vocation should be a long-term activity is threatened by (regionally varying) fluctuation among childminders [58], though a high level of turnover is not only a problem for childminding services, but affects the early childhood sector as a whole. Childminding can thus be regarded - taking into account its diversification regarding forms and activity profiles - as being in the process of becoming a vocation (Verberuflichung), though it is not equally far advanced in all areas.

But even for the occupational situation of early years practitioners in children's day-care centres, not all the requirements of a vocation in the sense described above have been fulfilled. Fuchs-Rechlin [34] has pointed out that in recent years fixed-term contracts for Erzieher / innen have increased disproportionately. This 
development is contrary to the wishes of Erzieher/innen, who regard secure, permanent employment as the most important aspect of a "good job" [35]. Besides this, atypical forms of employment such as contracts for less than 21 hours per week or marginal employment (geringfogige Beschdftigungen) are on the increase, especially in the western states of Germany. This is precarious, insofar as one cannot earn enough to live on with a part-time job. A further factor is the calculation of staff resources on the basis of parents' bookings - it seems to be common practice to base this calculation partly on the number of hours booked. The practitioners employed in day-care centres can therefore only plan one year ahead, since bookings can change from year to year.

Erzieher/innen and Kinderpfleger/innen with full-time jobs, however, can generally earn their own living, which puts them in a better economic position than working women as a whole [34]. Nonetheless, only $25 \%$ of practitioners are satisfied with the level of their income, while nearly half (49\%) state that they are somewhat or completely dissatisfied $[65 ; 86]$. In 2012 , $36 \%$ of pedagogical staff was working full time, i. e. 38.5 or more hours per week, $17 \%$ were working 32 to 38.5 hours per week, and just under half of practitioners were working fewer than 32 hours per week [65].

\section{Summary and conclusion}

In view of the increased demands made on children's day-care services, it has become apparent that professionalization in children's day care needs to be conceived more broadly than has hitherto been the case. It has become clear here that professionalization goes far beyond the individual competencies of practitioners, and addresses structures and conditions that imply collective societal responsibility. The concept of professionalization from the CoRe project, which is taken as the basis for this analysis, already takes into account various levels, but these have so far not been sufficiently related to each other. Up till now the individual competence of practitioners has often been considered in isolation, rather than in the context of underlying biographical, structural or organizational factors. It therefore seems worthwhile paying more attention in future to the structures at various levels of the system.

The levels derived from the CoRe study could be helpful when it comes to systematically assessing the influencing factors and inferring relationships between the levels and individuals. The Bundesarbeitsgemeinschaft "Bildung und Erziehung in der Kindheit e.V." (German Federal Working Group "Education and Care in Childhood") has adopted the idea of levels in its "Hamburg Declaration", identifying the requirements for the different levels (e.g. funding body and management, professional support, education and training) in order to further develop these [16].

In addition to this, there have been a number of developments in Germany which point in the same direction as the CoRe findings. These include the creation of competency profiles and qualification frameworks to lay the foundations for a coherent system of training and professional development. Moreover, a coordination unit entitled "Мдnner in Kitas" "Men in Day Care") has been set up to try to attract more male practitioners to the field. Continuous professional development is now seen as important for maintaining the professionalism of practitioners, even if pro- 
fessional development courses are still too short and are seldom completed as a team [12]. There is, however, still a great need for action, particularly at the political level, if a coherent system of early childhood education and care with improved working conditions is to be achieved.

Even if the structures need to be taken more into account, the processes of education and care continue to take place in direct interaction between practitioners and children, whose competencies play a major role in shaping these processes. High-quality early childhood education and care can only develop when struc- tures and actors work together, taking the needs of parents and children seriously. In this context it might be helpful to have a set of values, creating a common basis for children's day care and for professional ethics in early childhood education.

The main insight here is that, given the increased interest within society, there has never been a better time to push for a qualitative improvement in children's day care in Germany, even if the current focus is on the expansion of provision. This is an opportunity which cannot afford to be missed.

Статья поступила в редакиию 04.03.2019 2.

\section{REFERENCES}

1. Ahnert L. Wie viel Mutter braucht ein Kind. Bindung - Bildung - Betreuung: öffentlich und privat. Heidelberg, Spektrum Akademischer Verlag, 2010. 344 S.

2. Aktionsrat Bildung. Professionalisierung in der Frühpädagogik, 2012. Available at: http:// www.aktionsrat-bidung.de/fileadmin/Dokumente/Gutachten_Professionalisierung_in_ der_Fruehpaeda gogik.pdf (accessed: 28.08.2018).

3. Andermann H., Dippelhofer-Stiem B., Kahle I. ErzieherInnen vor dem. Eintritt in das Berufsleben. $\mathrm{Zu}$ ihren beruflichen Orientierungen und zur Beurteilung ihrer Ausbildung an der Fachschule für Sozialpädagogik. In: Zeitschrift für Frauenforschung und Geschlechterstudien, 1996, no. 14 (1+2), pp. 138-151.

4. Anders Y. Stichwort: Auswirkungen frühkindlicher institutioneller Betreuung und Bildung. In: Zeitschrift für Erziehungswissenschaft und Geschlechterstudien, 2013, no. 16 (2), pp. 237-275.

5. Arnold K.-H. Schulleistungsstudien und soziale Gerechtigkeit. In: Zeitschrift für Pädagogik, 2001, no. 47 (2), pp. 161-177.

6. Autorengruppe Bildungsberichterstattung. Ein indikatorengestützter Bericht mit einer Analyse zur Bildung von Menschen mit Behinderung. In: Bildung in Deutschland 2014. Bielefeld.

7. Autorengruppe Fachschulwesen. Qualifikationsprofil „Frühpädagogik“ - Fachschule/ Fachakademie, 2011. Available at: http://www.weiterbildungsinitiative.de/uploads/media/ WiFF_Kooperationen_1_Quali fikationsprofil_Internet.pdf (accessed: 28.08.2014).

8. Balluseck H. von. Frühpädagogik als Beruf und Profession. In: Balluseck H. von, ed. Professionalisierung der Frühpädagogik: Perspektiven, Entwicklungen, Herausforderungen. Opladen, Barbara Budrich. 2008.

9. Barthel M., Harth D., Scholz-Minkwitz E., Endrulat S., Schröder M., Ehlert H. Betätigung und Stimme von Erziehern in der Krippe. Ein interdisziplinärer primärpräventiver Ansatz. In: Prävention und Gesundheitsförderung, 2014, no. 9 (2), pp. 130-137.

10. Begemann M.-C., Kaufhold G. Erstaunliche Befunde - Ergebnisse einer U3-Vor-OrtElternbefragung. In: KomDat, 2012, no. 15 (3), pp. 7-10.

11. Beher K., Lange J. Kita-Leitung unter der Lupe. In: TPS, 2014, no. 2, pp. 14-17.

12. Beher K., Walter M. Bundesweite Befragung von Einrichtungsleitungen und Fachkräften in Kindertageseinrichtungen: Zehn Fragen - Zehn Antworten. WiFF Studien 15. In: Qualifikationen und Weiterbildung frühpädagogischer Fachkräfte. München, DJI, 2012. 
13. Bertelsmann Stiftung. 7 Antworten der Bertelsmann Stiftung. Status quo, Handlungsbedarfe und Empfehlungen. Methodische Erläuterungen. Gütersloh. In: Qualitätsausbau in KiTas. 7 Fragen zum Qualitätsausbau in deutschen KiTas. 2014.

14. BKK Gesundheitsreport. In: Gesundheit in Bewegung. Schwerpunkt Muskel- und Skeletterkrankungen. Berlin, 2013.

15. Bock-Famulla K., Lange J. Länderreport Frühkindliche Bildungssysteme 2013. Transparenz schaffen - Governance stärken. Gütersloh, 2013.

16. Bundesarbeitsgemeinschaft „Bildung und Erziehung in der Kindheit" e.V. (BAG BEK e.V.). In: Das System vom Kind her denken. Zur Weiterentwicklung des Systems der Kindertagesbetreuung in Deutschland. 2014 Hamburger Erklärung. Available at: http://www.bag-bek.eu/images/ Tagungen/Hamburg_2014/Hamburger_Erklaerung-2014.pdf (accessed: 29.08.2014).

17. Bundesarbeitsgemeinschaft der Landesjugendämter BAGLJÄ. Empfehlungen zur Fachberatung.2003. Availableat:http://www.bagljae.de/downloads/091_fachberatung_2003. pdf (accessed: 27.08.2014).

18. Bundesministerium für Familie, Senioren, Frauen und Jugend. Kinder - und Jugendbericht. Bericht über die Lebenssituation junger Menschen und die Leistungen der Kinder - und Jugendhilfe in Deutschland. Berlin, 2013.

19. Bundesministerium für Familie, Senioren, Frauen und Jugend. In: Familien mit Migrationshintergrund. Lebenssituationen, Erwerbsbeteiligung und Vereinbarkeit von Familie und Beruf. Berlin, 2010.

20. Cloos P. Konturen einer kindheitspädagogischen Professionsforschung. In: Betz T., Cloos P., eds. Kindheit und Profession. Konturen und Befunde eines Forschungsfeldes. Weinheim, Basel, 2014.

21. Cloos P. Die Inszenierung von Gemeinsamkeit. Eine vergleichende Studie zu Biographie, Organisationskultur und beruflichem Habitus von Teams in der Kinder-und Jugendhilfe. Weinheim, München, Juventa, 2008. 334 s.

22. Combe A., Helsper W. Pädagogische Professionalität. Frankfurt a. M., Suhrkamp, 1996.

23. Cryer D., Tietze W., Burchinal M., Leal T., Palacios J. Predicting Process Quality from Structural Quality in Preschool Programs: A Cross-Country Comparison. In: Early Childhood Research Quarterly, 1999, no. 14 (3), pp. 339-361.

24. Daheim H. Zum Stand der Professionssoziologie. Rekonstruktion machtheoretischer Modelle der Profession. In: Dewe B., Ferchhoff W., Radtke F.-O., hrsgs. Erziehen als Profession. Zur Logik professionellen Handelns in pädagogischen Feldern. Opladen, 1992, pp. 21-35.

25. Deutscher Verein für öffentliche und private Fürsorge e.V. Empfehlungen des Deutschen Vereins zur konzeptionellen und strukturellen Ausgestaltung der Fachberatung im System der Kindertagesbetreuung. Berlin, 2012.

26. Dippelhofer-Stiem B. Fachschulen für Sozialpädagogik aus der Sicht von Absolventinnen. Ergebnisse einer empirischen Studie. In: Thiersch R., Höltershinken D., Neumann K., eds. Die Ausbildung der ErzieherInnen. Entwicklungstendenzen und Reformansätze. Weinheim, München, Juventa, 1999, pp. 80-92.

27. Dippelhofer-Stiem B. Berufliche Sozialisation von Erzieherinnen. In: Fried L., Roux S., eds. Handbuch Pädagogik der frühen Kindheit. Berlin, Cornelsen, 2013, pp. 400-410.

28. Dippelhofer-Stiem B., Kahle I. Die Erzieherin im evanglischen Kindergarten. Analysen zum professionellen Selbstbild des pädagogischen Personals, zur Sicht der Kirche und zu den Erwartungen der Eltern. Bielefeld, Kleine, 1995.

29. Early D. M., Maxwell K. L., Burchinal M. et al. Teachers' Education, Classroom Quality, and Young Children's Academic Skills: Results from seven studies of Preschool Programs. In: Child Development, 2007, no. 78 (2), pp. 558-580.

30. Early D. M., Iruka I. U., Ritchie S. et al. How Do Pre-Kindergarteners Spend Their Time? 
Gender, Ethnicity, and Income as Predictors of Experiences in Pre-Kindergarten Classrooms. In: Early Childhood Research Quarterly, 2010, no. 25 (2), pp. 177-193.

31. European Commission. In: Early Childhood Education and Care: Providing all our children with the best start for the world of tomorrow. COM, 66 final. Brussels, 2011.

32. Fried L. Bildung und didaktische Kompetenz. In: Thole W., Rossbach H.-G., FöllingAlbers M., Tippelt R., eds. Bildung und Kindheit: Pädagogik der Frühen Kindheit in Wissenschaft und Lehre. Opladen, Barbara Budrich, 2008, pp. 141-152.

33. Friederich T. Professionalisierung durch Akademisierung? Studiengänge für frühpädagogische Fachkräfte in Frankreich, Schweden, England und Dänemark. In: Zeitschrift für Sozialpädagogik, 2012, no. 10 (1), pp. 41-60.

34. Fuchs-Rechlin K. Die berufliche, familiäre und ökonomische Situation von Erzieherinnen und Kinderpflegerinnen. Frankfurt a. M., GEW, 2010.

35. Fuchs T., Trischler F. Arbeitsqualität aus Sicht von Erzieherinnen und Erziehern. Ergebnisse aus der Erhebung zum DGB-Index Gute Arbeit. Frankfurt a. M., GEW, 2009.

36. Fukkink R. G. Does training matter? A meta-analysis and review of caregiver training studies. In: Early Childhood Research Quarterly, 2007, no. 22, pp. 294-311.

37. Graue E., Rauscher E., Sherfinski M. The Synergy of Class Size Reduction and Classroom Quality. In: The Elementary School Journal, 2009, no. 110 (2), pp. 178-201.

38. Heckman J. The Economics of Inequality. The Value of Early Childhood Education. In: American Educator, 2011, Spring, pp. 31-47.

39. Helm J. Das Bachelorstudium Frühpädagogik. Zugangswege - Studienzufriedenheit Berufserwartungen. Ergebnisse einer Befragung von Studierenden. WiFF Studien 5. München, DJI, 2011.

40. Helsper W., Tippelt R. Ende der Profession oder Professionalisierung ohne Ende? Zwischenbilanz einer unabgeschlossenen Diskussion. In: Zeitschrift für Pädagogik. Sonderheft Pädagogische Professionalität, 2011, pp. 268-288.

41. Kahle I. Grenzen der Erziehungsarbeit. Über Belastungen im beruflichen Alltag von Erzieherinnen. In: Diskurs, 1999, no. 9 (1), pp. 68-77.

42. Kerl-Wienecke A., Schoyerer G., Schuhegger L. Kompetenzprofil Kindertagespflege in den ersten drei Lebensjahren. Berlin, Cornelsen, 2013.

43. Klaudy E. K., Schütz A., Stöbe-Blossey S. Akademisierung der Ausbildung für die Kindertageseinrichtung. Zur Entwicklung kindheitspädagogischer Studiengänge. IAQReport. Universität Duisburg-Essen. 04/2014.

44. KMK / JFMK Gemeinsamer Orientierungsrahmen „Bildung und Erziehung in der Kindheit“, 2010. Available at: http://www.kmk.org/fileadmin/veroeffentlichungen_ beschluesse/2010/2010_09_16-Ausbildung-Erzieher-KMK-JFMK.pdf (accessed: 29.08.2014).

45. Kobelt Neuhaus D., Refle G. Inklusive Vernetzung von Kindertageseinrichtung und Sozialraum. WiFF Expertise Nr. 37. München, DJI, 2013.

46. Kohli M. Die Institutionalisierung des Lebenslaufs. Historische Befunde und theoretische Argumente. In: Kölner Zeitschrift für Soziologie und Sozialpsychologie, 1985, no. 37 (1), pp. 1-29.

47. Kohli M. Normalbiographie und Individualität. Zur institutionellen Dynamik des gegenwärtigen Lebenslaufregimes. In: Brose H.-G., Hildenbrand B., eds. Vom Ende des Individuums zur Individualität ohne Ende. Opladen, Leske und Budrich, 1988, pp. 33-53.

48. König A. Interaktionsprozesse zwischen ErzieherInnen und Kindern. Eine Videostudie aus dem Kindergartenalltag. Wiesbaden, VS Verlag für Sozialwissenschaften, 2009.

49. Kuger S., Kluczniok K. Prozessqualität im Kindergarten: Konzept, Umsetzung und Befunde. In: Zeitschrift für Erziehungswissenschaften 10, Sonderheft, 2008, no. 11, pp. 159-178. 
50. Leygraf J. Fachberatung in Deutschland. Eine bundesweite Befragung von Fachberaterinnen und Fachberatern für Kindertageseinrichtungen: Zehn Fragen - Zehn Antworten. WiFF Studien 20. München, DJI, 2013.

51. Lüders M.Problemevon Lehrerinnen und Lehrern mitder Beurteilung von Schülerleistungen. In: Zeitschrift für Erziehungswissenschaft, 2001, no. 4 (3), pp. 457-474.

52. Mayer K. U., Müller W. Lebensverläufe im Wohlfahrtsstaat. In: Weymann A., ed. Handlungsspielräume: Untersuchungen zur Individualisierung und Institutionalisierung von Lebensläufen in der Moderne. Stuttgart, Enke, 1989, pp. 41-60.

53. Mischo C., Wahl S., Hendler J., Strohmer J. Pädagogische Orientierungen angehender frühpädagogischer Fachkräfte an Fachschulen und Hochschulen. In: Frühe Bildung, 2012, no. 1 (1), pp. 34-44.

54. Nentwig-Gesemann I., Fröhlich-Gildhoff K., Harms H., Richter S. Professionelle Haltung Identität der Fachkraft für die Arbeit mit Kindern in den ersten drei Lebensjahren. WiFF Expertisen 24. München, DJI, 2011.

55. Oberhuemer P., Schreyer I. Kita-Fachpersonal in Europa: Ausbildungen und Professionsprofile. Opladen, Farmington-Hill, Barbara Budrich, 2010.

56. OECD. Starting Strong II. Early Childhood Education and Care. Paris, OECD, 2006.

57.Osgood J. Reconstructing professionalism in ECEC: the case for the 'critically reflexive emotional professional'. In: Early Years, 2010, no. 30 (2), pp. 119-133.

58. Pabst C., Schoyerer G. Wie entwickelt sich die Kindertagespflege in Deutschland? Empirische Befunde und Analysen aus der wissenschaftlichen Begleitung des Aktionsprogramms Kindertagespflege. Weinheim, Basel, Juventa, 2015.

59. Pianta R. C., LaParo K. M., Hamre B. K. The Classroom Assessment Scoring System. Baltimore, Brookes, 2008.

60. Powell D. R., Diamond K. E., Cockburn M. K. Promising Approaches to Professional Development for Early Childhood Educators. In: Saracho O. N., Spodek B., eds. Handbook of Research on the Education of Young Children. New York, Routledge, 2013, pp. 385-392.

61. Rauschenbach Th. Der Preis des Aufstiegs? Folgen und Nebenwirkungen einer frühpädagogischen Qualifizierungsoffensive. In: Berth F., Diller A., Nürnberg C., Rauschenbach Th. Gleich und doch nicht gleich. Der Deutsche Qualifikationsrahmen und seine Folgen für frühpädagogische Ausbildungen. München, DJI, 2013, pp. 15-38.

62. Rauschenbach Th., Schilling M. Das U3-Projekt - zum Platz - und Personalbedarf. In: Arbeitsgemeinschaft Jugendhilfe, ed. Chancen und Herausforderungen des Ausbaus der Kindertagesbetreuung für unter Dreijährige. Berlin, 2013, pp. 43-50.

63. Santen E von. Präsentation der ersten vorläufigen Ergebnisse zur DJI-Kita-Studie. München, 2013.

64. Schoyerer G. Kindertagespflege zwischen Anspruch und Wirklichkeit - Pädagogische Orientierungen in der Fachberatung. Marburg, Tectum, 2014.

65. Schoyerer G. Fachberatung in der Kindertagespflege. Praxismaterialien für die Jugendämter, Nr. 5, 2012. Available at: http://www.fruehe-chancen.de/files/bilder/application/pdf/ handreichung_fachberatung_in_der_kindertag espflege.pdf (accessed: 27.08.2014).

66. Schoyerer G., Santen E. van, revs: Child Care in a Context of Social Heterogeneity and Inequality. In: Empirical Notes on an Interdisciplinary Challenge.

67. Schoyerer G., Weimann-Sandig N. Tagespflegepersonen in tätigkeitsbegleitender ErzieherInnenausbildung. Die Sicht von Tagespflegepersonen auf Berufsmotivation, Alltagsmanagement und öffentliche Förderung. München, 2015.

68. Schreyer I., Krause M., Nicko O. et al. Qualität der Arbeitsverhältnisse und Arbeitsbedingungen frühpädagogischer Fachkräfte in Deutschland. Vortrag auf der AWiFF- 
Tagung, 2014. Available at: http://www.weiterbildungsinitiative.de/fileadmin/download/ Veranstaltungen/AWiFF_AQUA_Panel_3.pdf. (accessed: 27.08.2014).

69. Sell S., Kukula N. Vergütung in der Kindertagespflege. Bestandsaufnahme und Modelle einer leistungsorientierten Vergütungssystematik. Remagen, ibus-Verlag, 2013.

70. Statistisches Bundesamt. Statistik der Kinder - und Jugendhilfe. Kinder und tätige Personen in Tageseinrichtungen und öffentlich geförderter Kindertagespflege. Wiesbaden, 2013.

71. Stichweh R. Professionen in einer funktional differenzierten Gesellschaft. In: Combe A., Helsper W., eds. Pädagogische Professionalität. Frankfurt a. M., 1996, pp. 49-69.

72. Strehmel P., Ulber D. Leitungen von Kindertageseinrichtungen. WiFF Expertise Nr. 39. Deutsches Jugendinstitut. München, 2014.

73. Sylva K., Melhuish E. C., Sammons P. et al. The Effective Provision of Pre-School Education Project $-\mathrm{Zu}$ den Auswirkungen vorschulischer Einrichtungen in England. In: FaustSiehl G., Götz M., Hacker H., RoЯbach H.-G., eds. Anschlussfähige Bildungsprozesse im Elementar-und Primarbereich. Bad Heilbrunn, Klinkhardt, 2004, pp. 154-167.

74. Thole W. „Professionalisierung“ der Pädagogik der Kindheit. In: Thole W., Rossbach H.-G., Fölling-Albers M., Tippelt R., eds. Bildung und Kindheit: Pädagogik der Frühen Kindheit in Wissenschaft und Lehre. Opladen, Verlag Barbara Budrich, 2008, pp. 271-295.

75. Thole W. Die pädagogischen MitarbeiterInnen in Kindertageseinrichtungen. Professionalität und Professionalisierung eines pädagogischen Arbeitsfeldes. In: Zeitschrift für Pädagogik, 2010, no. 56 (2), pp. 206-222.

76. Thole W. Was bedeutet Professionalisierung? Theoretische Herausforderungen und empirische Befunde. Vortrag auf der ersten Kolloquiumsveranstaltung "Professionalisierung in der Kindertagesbetreuung", 2013. Available at: http://www.weiterbildungsinitiative.de/ fileadmin/download/Veranstaltungen/2013102 5_Werner_Thole.pdf(accessed: 27.08.2014).

77. Tietze W., Becker-Stoll F., Bensel J. et al., eds. Nationale Untersuchung zur Bildung, Betreuung und Erziehung in der frühen Kindheit (NUBBEK). Berlin, Verlag das netz, 2013.

78. Tietze W., Lee H.-J. Ein System der Evaluation, Verbesserung und Zertifizierung pädagogischer Qualität von Kindertageseinrichtungen in Deutschland. In: Altgeld K., Stöbe-Blossey S., eds. Qualitätsmanagement in der frühkindlichen Bildung, Erziehung und Betreuung. Perspektiven für eine öffentliche Qualitätspolitik. Wiesbaden, VS Verlag für Sozialwissenschaften, 2009, pp. 43-62.

79. Tietze W., Rossbach R.-G., Grenner K. Kinder von 4 bis 8 Jahren. Zur Qualität von Erziehung und Bildung in Kindergarten, Grundschule und Familie. Weinheim, Basel, Beltz, 2005.

80. Tietze W., ed. Wie gut sind unsere Kindergärten? Eine empirische Untersuchung zur pädagogischen Qualität in deutschen Kindergärten. Neuwied, Luchterhand, 1998.

81. UNESCO. Results from the OECD Thematic Review of Early Childhood Ecudation and Care Policy 1998-2006. In: UNESCO Policy Brief on Early Childhood, 2007, no. 41.

82. UNESCO. Curriculum in Early Childhood Education and Care. In: UNESCO Policy Briefon Early Childhood, 2004, no. 26.

83. UNESCO. The Eary Childhood Workforce in "Developed" Countries: Basic Structures and Education. In: UNESCO Policy Brief on Early Childhood, 2004, no. 27.

84. Urban M., Vandenbroeck M., Laere K. von et al. Towards Competent Systems in Early Childhood Education and Care. Implications for Policy and Practice. In: European Journal of Education, 2012, no. 47 (4), pp. 508-526.

85. Urban M., Vandenbroeck M., Laere K. von et al. CoRe. Competence Requirements in Early Childhood Education and Care. A Study for the European Commission Directorate-General for Education and Culture: Final Report, 2011. Available at: www.vbjk.be/files/CoRe\%20 Final\%20Report\%202011.pdf (accessed: 27.08.2014). 
86. Viernickel S., Voss A. STEGE Strukturqualität und Erzieher_innengesundheit in Kindertageseinrichtungen. Wissenschaftlicher Abschlussbericht, 2013. Available at: http:// www.gew.de/Binaries/Binary109551/STEGE_NRW_Abschlussbericht.pdf (accessed: 27.08.2014).

87. Viernickel S., Nentwig-Gesemann I., Nicolai K. et al. Schlüssel zu guter Bildung, Erziehung und Betreuung - Bildungsaufgaben, Zeitkontingente und strukturelle Rahmenbedingungen in Kindertageseinrichtungen, 2013. Available at: http://www.gew.de/Binaries/Binary96129/ Expertise_Gute_Bildung_2013.pdf (accessed: 27.08.2014).

88. Wertfein M., Müller K., Danay E. Die Bedeutung des Teams für die Interaktionsqualität in Kinderkrippen. In: Frühe Bildung, 2013, no. 2 (1), pp. 20-27.

\section{ИНФОРМАЦИЯ ОБ АВТОРАХ}

Тина Фридрих - доктор философских наук, профессор педагогики факультета социальной работы Католического университета прикладных наук г. Мюнхена; e-mail: tina.friederich@ksh-m.de;

Габриэль Шойерер - доктор философских наук, профессор педагогики факультета социальной работы Католического университета прикладных наук г. Мюнхена; e-mail: gabriel.schoyerer@ksh-m.de

\section{INFORMATION ABOUT THE AUTHORS}

Tina Friederich - Doctor of Philosophy, Professor of Pedagogy at the Department of Social Work of Katholische Stiftundshochschule Mrnchen; e-mail: tina.friederich@ksh-m.de;

Gabriel Schoyerer - Doctor of Philosophy, Professor for Childhood Education and Care at the Department of Social Work of Katholische Stiftungshochschule Mьnchen; e-mail: gabriel.schoyerer@ksh-m.de

\section{ПРАВИЛЬНАЯ ССЫЛКА НА СТАТЬЮ}

Фридрих Т., Шойерер Г. Профессионализация немецкой системы дневного ухода за маленькими детьми - о взаимоотношениях между практиками, структурами и контекстами // Вестник Московского государственного областного университета. Серия: Психологические науки. 2019. № 2. С. 106-125.

DOI: $10.18384 / 2310-7235-2019-2-106-125$

\section{FOR CITATION}

Friederich T., Schoyerer G. Professionalization of Germany's Day Care System for Young Children - On the Relationship between Practitioners, Structures and Contexts. In: Bulletin of the Moscow Region State University. Series: Psychology, 2019, no. 2, pp. 106-125.

DOI: $10.18384 / 2310-7235-2019-2-106-125$ 